\title{
"Monarquia mais dilatada que se viu no mundo": considerações sobre dimensão de domínios e imaginação política em frontispícios no império espanhol ${ }^{*}$
}

Jorge Victor de Araújo Souza

\section{RESUMO}

Segundo o autor seiscentista Sebastian Covarrubias Orozco, o ato de representar era fazer presente alguma coisa usando palavras ou figuras. Tal processo, afirma, era essencial para fixar algo na imaginação. Partindo da análise de gravuras em frontispícios e outras imagens, este artigo traça considerações acerca da relação entre imaginação política e dimensão do domínio espanhol. O debate sobre representação figurativa contribui para o entendimento da cultura política na Época Moderna ao propor reflexão sobre as relaçôes entre os espaços constituintes de um império ultramarino.

Palavras-chave: imaginação política; frontispícios; gravuras; império espanhol; iconografia.

\section{ABSTRACT}

According to seventeenth-century author Sebastian Covarrubias Orozco, representation consists in making something present through words or figures. This process, he pondered, was essential to record something in one's imagination. Departing from an analysis of frontispieces' engravings and other images, this article considers the relationship between political imagination, on one hand, and the extension of the Spanish dominion, on the other. The debate on figurative representation contributes to the understanding of political culture in Modern Age, as it suggests a reflection on the accurate dimensions of an overseas empire. Keywords: political imagination; frontispieces; engravings; Spanish empire; iconography. 
Si bien el buril y el pincel son lenguas mudas, persuaden tanto como las mas fecundas ${ }^{l}$

Diego Saavedra Fajardo

A frase do escritor espanhol, autor de empresas políticas no seiscentos, vincula-se à tópica Ut pictura poesis, máxima horaciana sobre a relação entre pintura e poesia dominante na retórica moderna. Fajardo salienta um aspecto na tensão entre as práticas discursivas - o convencimento por meio de representaçôes figurativas. O escritor de Idea de um príncipe político-christiano vai além, ao demonstrar como essas representaçôes são importantes instrumentos para criação de dispositivos de memorização de feitos, algo extremamente útil ao aprendizado de virtudes de acordo com a cultura visual do período. Nesse sentido, partindo das produçóes do século XVII, estudaremos a sobrevivência de imagens gravadas: campo da representação. No dezessete, representação tinha entre outras funções tornar "presente alguna cosa con palabras, o figuras que se fixan en nuestra imaginación". ${ }^{2}$ As gravuras e os frontispícios, sobretudo pela relação entre imagem e texto, não apenas fixam algo na imaginação, como também servem de modelos para outras imaginaçóes. ${ }^{3}$

Considerando que frontispícios e gravuras são relevantes fontes para o estudo da retórica figurativa, trataremos das maneiras como o império espanhol foi representado. Enfocaremos uma tópica: a universalidade. Como bem salientou Antonio Miguel Bernal, monarquia universal e monarquia espanhola acabaram por se tornar sinônimas. ${ }^{4}$ A partir dessa afirmação, acreditamos que durante a Época Moderna, mormente na primeira metade do século XVII, uma determinada imagem foi muito vulgarizada operando a articulaçáo de um conjunto de atributos iconográficos que faziam referência à dimensão planetária do império espanhol

${ }^{1}$ FAJARDO, Diego Saavedro. Idea de un principe politico-christiano. Valencia, 1800. Tomo I, p. 18.

${ }^{2}$ COVARRUBIAS OROZCO, Sebastian. Tesoro de la lengua castellana, o española. Madri, 1611. p. 1260.

${ }^{3}$ Pierre Civil, professor da Sorbonne, especialista na sociedade espanhola nos séculos XVI e XVII, considera o frontispício como parte fundamental de uma edição. Para Civil, tais imagens estáo impregnadas de discursos pré-textuais que podem muito bem servir como fontes para pesquisas em torno das relaçóes de poder, como demonstra sua análise do frontispício de uma edição da Historia de las ordenes militares de Santiago, Calatrava y Alcántara, publicada em 1629, onde aponta as representaçôes do Conde Duque de Olivares em relação às do próprio rei. CIVIL, Pierre. Libro y poder real: sobre algunos frontispícios da primera mitad del siglo XVII. In: REDONDO, Augustín; GARCÍA, Pedro Manuel (Coord.). El escrito em el Siglo de Oro: praticas y representaciones. Salamanca: Universidade de Salamanca, 1999. p. 69-83. Já Marc Fumaroli, outro historiador francês, na década de 1990 demonstrou as maneiras como os frontispícios podem ser instigantes objetos para o estudo histórico. O interesse de Fumaroli é centrado nas práticas retóricas dos séculos XVI e XVII. O entrelaçamento entre textos e imagens gravadas para formação de discursos sobressai em sua análise do frontispício de um panegírico jesuítico de suma importância — o Imago primi saeculi Societas de Jesu, editado em Antuérpia, no ano de 1640 —, que, segundo sua constataçáo, está situado entre o barroco e o classicismo. FUMAROLI, Marc. Baroque et classicisme: L'Imago primi saeculi Socitatis Jesu (1640) et ses adversire's. in: L'école du silence. Le sentiment des images au XVIIe siècle. Paris: Flammarion, 1994. p. 343-365.

${ }^{4}$ BERNAL, Antonio Miguel. España, proyecto inacabado. Los costes/benefícios del Imperio. Madri: Marcial Pons, 2007. p. 82. 
e que buscavam persuadir o espectador da existência da imensidão de seu domínio e de sua unidade, constituindo uma "retórica visual da mundialização". Essa retórica pode ser percebida nos discursos de obras de variados gêneros e de épocas distintas, sendo inclusive reproduzida na América.

Francisco Cabrera (1780-1845) produziu gravuras para ornar um folheto publicado em 1809, denominado Guatemala por Fernando VII (figura 1), cujo objetivo principal era descrever as maneiras pelas quais os guatemaltecos, em 1808, juraram fidelidade ao monarca espanhol aprisionado por Napoleão Bonaparte.

Figura 1

\section{Guatemala por Fernando VII, 1809. Gravura do apêndice 25.}

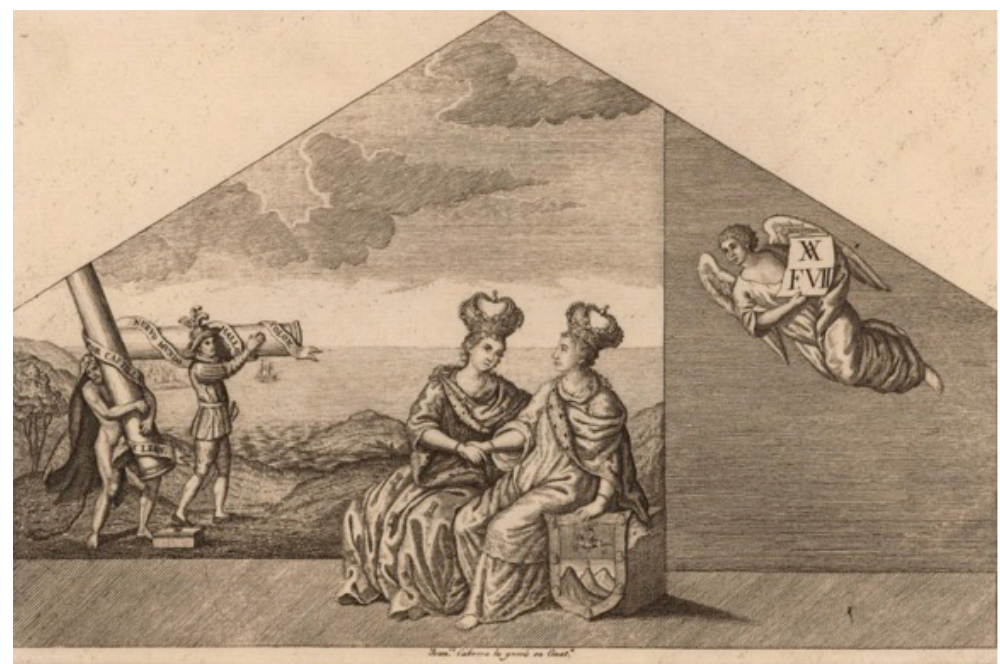

Fonte: Cortesia da Biblioteca John Carter Brown, da Brown University.

Na gravura, Castela e Guatemala são representadas como duas mulheres sentadas. Coroadas e vestidas majestaticamente, as duas personificaçóes apertam as mãos em sinal de amizade e de apoio. A cumplicidade é reforçada pela troca de olhares. Distinguindo-se da amiga europeia, Guatemala sustenta um escudo com suas armas, e, por seus atributos, é saliente que sua representação está distante das formas com que a América e suas regiôes foram

\footnotetext{
${ }^{5}$ Esta concepção de mundialização a qual me refiro pode ser observada, sobretudo, nos estudos do historiador Serge Gruzinski. GRUZINSKI, Serge. Las cuatro partes del Mundo. Historia de una mundialización. México: FCE, 2010. Sobre "retórica visual", ver: LINCHTENSTEIN, Jacqueline. La couleur eloquente. Rhétorique et peinture à L’Âge Classique. Paris: Flammarion, 1989.
} 
representadas na Época Moderna — nesta gravura ela não é uma "selvagem". Ela se iguala à Europa. No lado direito da estampa, há um anjo apresentando as iniciais de Fernando VII, única referência religiosa na iconografia. No esquerdo, dois homens erguem colunas unidas por um faixa onde está inscrito "Colon hallo Nuevo Mundo por Castilla y Leon". Um deles, vestido como fidalgo, inclusive com uma espada embainhada, caminha com uma coluna sobre o ombro, enquanto o outro, vestindo uma pele de leáo, acomoda a outra coluna em um ponto específico assinalado por uma base.

A historiadora Jordana Dym, professora do Skidmore College, em Nova York, estudou os hieróglifos e os emblemas no referido folheto feito por Antonio Juarros, membro do Cabildo. ${ }^{6}$ Entretanto, Dym não atentou para as duas colunas presentes na gravura do apêndice 25 , concentrando suas análises nas demonstraçôes públicas que os vassalos prepararam em lealdade ao monarca distante. A representação de tais colunas na configuração de um império em crise é mais do que adequada aos apelos simbólicos. São as colunas de Hércules, como indica o próprio personagem mítico, que na gravura sustenta uma delas. Esta é uma iconografia forjada muito antes das tensóes que abalaram a soberania espanhola. Iconografia antiguíssima, recuperada no começo do século XVI, sendo, como ressaltaremos, considerada tema propício às representaçóes imperiais.

A inscrição entrelaçada nas colunas é uma inversão, sem perda de sentido, da cota de armas de Cristovão Colombo. ${ }^{7}$ Ao fundo da cena principal, um navio faz referência às navegaçóes e à descoberta do Novo Mundo.

Há uma recorrência iconográfica nas representaçôes das míticas colunas: são carregadas em referência ao feito do herói. De acordo com a narrativa mitológica, para realizar um dos 12 trabalhos, Hércules abriu um caminho empurrando com os ombros um monte à entrada do estreito de Gibraltar, fincando dois pilares, de um lado o monte Calpe em Gibraltar e do outro o monte Hacho em Ábila (Ceuta). O mundo até então conhecido era delimitado por dois marcos: um na Europa e outro no norte da África. A iconografia clássica deste feito descreve Hércules com as duas colunas sobre os ombros, como na gravura de Hans Sebald Beham, de 1545, ou na de Heinrich Aldegrever, de 1550.

Em nenhuma iconografia anterior à produzida para Guatemala por Fernando VII Hércules divide seu fardo com outra personagem. Ao utilizar as colunas de Hércules em sua gravura, Francisco Cabrera evocou uma poderosa imagem de vinculação entre o Velho e o Novo Mundo. Algo que fazia parte de uma tradição representacional. Cabrera sintetizou

\footnotetext{
${ }^{6}$ DYM, Jordana. Ensenanza en los jeroglíficos y emblemas. Igualdad y lealtad en Guatemala por Fernando VII (1810), in Secuencia. Revista de historia e Ciencias Sociales, num. Conmemorativo, México, p. 75-102, 2008.

${ }^{7}$ Este mote é lembrado por um insigne jesuíta português ao tratar dos descobrimentos: "Deram-lhe armas de cavalheiro e pôs nelas Colon por orla, esta letra: Por Castilla y Aragon, Nuevo Mundo halló Colon. E desta casa descendem hoje os Almirantes das Índias de Castela, com titulo de Duques de Beragua”. VASCONCELLOS, Simão de. Chronica da Companhia de Jesu do Estado do Brasil e do que obraram seus filhos nesta parte do Novo Mundo. Lisboa: Typographia do Panorama, 1865. v. I, p. 30.
} 
uma ideia antiga ao introduzir um personagem vestido como um aristocrata hispânico (seria o próprio Colombo?) carregando uma das colunas: a Espanha era a responsável pelo posicionamento dos marcos do mundo.

Estudando a imaginação política no império espanhol, Anthony Pagden apontou um paradoxo quando analisou uma pintura de Giambatista Tiepolo (1696-1770) sobre a apoteose da Espanha, que se encontra na Sala do Trono do Palácio Real, em Madri. ${ }^{8}$ Trata-se de uma figura feminina cercada pelas colunas de Hércules e pela alegoria da Igreja. Uma pintura sobre a grandeza imperial, realizada no momento em que o império já não possuía a grandiloquência de outrora. Há uma tradição imagética. Buscaremos traçar algumas tópicas do percurso iconográfico dessa ideia e suas reapropriaçóes nos diversos trânsitos atlânticos, entendendo, como propôs Michael Baxandall, que toda descrição de uma imagem encerra uma boa dose de explicação.?

\section{Marcos da mundialização}

Rosenthal Earl, historiador da arte, foi o único pesquisador a se interessar de forma sistemática pelo tema iconográfico das colunas de Hércules na cultura política ibérica. Seus dois artigos, publicados na década de 1970 no conceituado periódico do Warburg Institute, enfocam a "invenção" das colunas de Hércules durante o Século de Ouro. No entanto, Earl se ateve a essa época, não se interessando pelas reapropriações imagéticas da temática.

Representaçóes das colunas de Hércules na Antiguidade e na Idade Média, de acordo com Earl, são encontradas em pouquíssimos mapas do Império Romano e em algumas tradições ptolomaicas. ${ }^{10}$ Earl demonstra que não houve uma convenção bem estruturada para a iconografia em questão, até a entrada de Carlos V na Ordem do Tosão de Ouro, em 1516. $\mathrm{O}$ ambiente literário ítalo-borgonhês foi propício à escolha das colunas, juntamente com o mote plus ultra, para representar a amplitude do domínio de Carlos V, que a partir de 1519 tornou-se imperador do Sacro Império Romano-Germânico. ${ }^{11} \mathrm{O}$ non plus ultra era um aler-

\footnotetext{
8 PAGDEN, Anthony. Spanish imperialism and the political imagination. Studies in European and Spanish-American social and political theory, 1513-1830. New Haven: Yale Press, 1990. p. 1.

${ }^{9}$ BAXANDALL, Michael. Padróes de intenção. A explicação histórica dos quadros. São Paulo: Companhia das Letras, 2006. p. 31-44.

${ }^{10}$ EARL, Rosenthal. The invention of the columnar device of emperor Charles $\mathrm{V}$ at the Court of Borgundy in Flanders in 1516. Journal of the Warburg and Courtauld Institute, v. 36, p. 198-230, p. 220, 1973.

${ }^{11}$ Um levantamento do debate historiográfico sobre Carlos $\mathrm{V}$ e a temática do poder imperial foi realizado por Ana Paula Vosne Martins, que salientou a heterogeneidade das pesquisas empreendidas em diversos países, assim como as distintas abordagens empregadas. MARTINS, Ana Paula Vosne. Milles christianus: Carlos V e o tema imperial. In: DORÉ, Andréa; LIMA, Luís Filipe Silvério; SILVA, Luiz Geraldo (Org.). Facetas do império na história: conceitos e métodos. São Paulo: Hucitec, 2008. p. 212-223.
} 
ta, um impedimento de se ir mais adiante a uma empreitada, aparecendo com este sentido na obra de Dante Alighieri juntamente com as colunas de Hércules. ${ }^{12}$ Em suas origens, o mote e as colunas não faziam referência ao Novo Mundo e ao domínio atlântico. Entretanto, como pretendo demonstrar, tais alusôes se tornaram comuns à vinculação atlântica.

O deslocamento das colunas de Hércules para os "novos mundos" se intensificou no final do século XVI e no começo do XVII, acompanhando o fluxo dos interesses mercantis e suas rotas. Redefinindo fronteiras, os símbolos passam a ser marcos definidores da equidistância espacial entre importantes pontos do império, como ficou gravado em um detalhe do frontispício da obra Nova typis transacta navigatio, publicada em 1621, em Linz, Áustria. Escrito por Caspar Plautius, um monge beneditino de Munique, o livro encerra um elogio a Bernard Boyl, monge de Monteserrat que acompanhou Cristovão Colombo em sua segunda viagem indo à Hispaniola, em 1493. Boyl, representado no frontispício batizando um índio ajoelhado, foi nomeado vigário geral das Índias pelo papa Alexandre VI. Ao lado contrário do beneditino, também com vestes monásticas, está São Brandonio (c. 484-c. 577), o Navegador, santo irlandês a quem é atribuída uma viagem mítica, porém baseada em alguns dados concretos de navegação. A "Ilha de São Brandão" foi representada em mapas até o século XVIII, e muitos navegadores a procuravam, pois, mesmo na Época Moderna, referências a espaços míticos e espaços reais conviviam nos imaginários e nas rotas.

Figura 2

PLAUTIUS, Caspar. Nova typis transacta navigatio. Linz, 1621.

Fig. 2a (detalhe do frontispício)
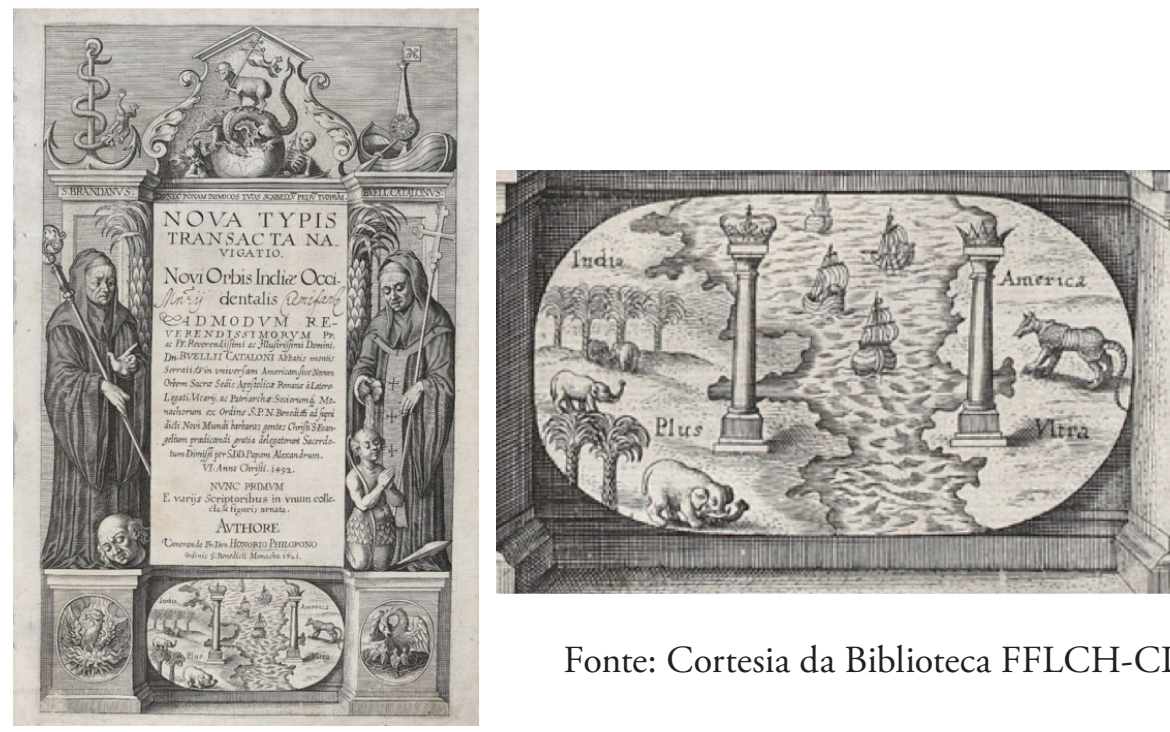

Fonte: Cortesia da Biblioteca FFLCH-CL-USP.

\footnotetext{
${ }^{12}$ EARL, Rosenthal. Plus ultra, non plus ultra, and the columnar device of emperor Charles V. Journal of the Warburg and Courtauld Institute, v. 34, p. 204-228, p. 212, 1971.
} 
Coroando o frontispício há um dragão enroscado em um globo. Juntamente com um esqueleto armado com arco e flecha e o próprio demônio, o dragão simboliza o mal que grassa a Terra. Com as patas sobre o dragão está o cordeiro de Deus, representando a salvação que se esperava ser assegurada com a missionação. A imagem é complementada com a passagem em latim na parte inferior do conjunto - Donec ponam inimicos tvos scabellv pedv tvorum —, retirada de Mateus 22:44: "Assenta-te à minha direita, até que eu ponha os teus inimigos debaixo de teus pés". Estes elementos formaram uma tópica presente em quase todos os frontispícios referentes à atuação de ordens religiosas no Novo Mundo. Para Jorge Cañizares-Esguerra, a tópica demonológica foi fundamental aos projetos imperiais, pois a ideia de uma guerra contra Satá fundamentava uma guerra santa nos territórios conquistados, onde alguns nativos eram considerados inimigos pagáos. ${ }^{13}$

Assim, frontispícios como o do Nova typis transacta encerram uma síntese imagética relevante na cultura política das conquistas ibéricas. O frontispício, como as outras 21 ilustraçóes do livro foram feitos por Wolfgang Killian (1581-1663), gravador de Aubsburgo. Tal aspecto aponta como a circularidade de ideias e formas atuava na condiçáa de produçáo de imagens gravadas que englobavam sujeitos oriundos de diversos espaços.

Apesar de ser uma memória dos feitos de um beneditino na América - vale destacar que essa ordem religiosa teve pouquíssima atuação na colonização da América hispânica, somente com uma tímida presença em Lima e no México, sendo mais atuante no Brasil —, o livro de Caspar Plautius deve ser entendido mais como discurso encomiástico sobre a expansão missionária de seus irmãos de hábito. Discurso relevante no contexto de disputas seiscentistas entre as diferentes ordens religiosas.

A posição das colunas de Hércules, colocadas entre dois pontos do globo - a Ásia com elefantes, conforme convencionou Cesare Ripa (1555-1622) na personificação do continente, e a América com um tatu gigantesco, de acordo com a gravura de Adriaen Colaert (15601618) —, denota a magnitude do espaço conquistado pelos espanhóis, recordando o mote fortalecido durante o reinado de Filipe II: "O Sol não se pôe no Império". ${ }^{14}$ Mudanças nas conjunturas, mudanças na semântica imagética. De uma iconografia que estabelecia os limites do mundo, as colunas têm sua significaçáo ampliada para abarcar a balizagem de um espaço imperial além-mar.

\footnotetext{
${ }^{13}$ CAÑIZARES-ESGUERRA, Jorge. Católicos y puritanos en la colonización de América. Madri: Marcial Pons, 2008. p. 164.

${ }^{14}$ BERNAL, Antonio Miguel. España, proyecto inacabado, op. cit. p. 28.
} 
Figura 3

\section{DAVILA, Gil Gonzalez. Teatro eclesiastico de la primitiva Iglesia de las Indias occidentales. Madri, 1655.}

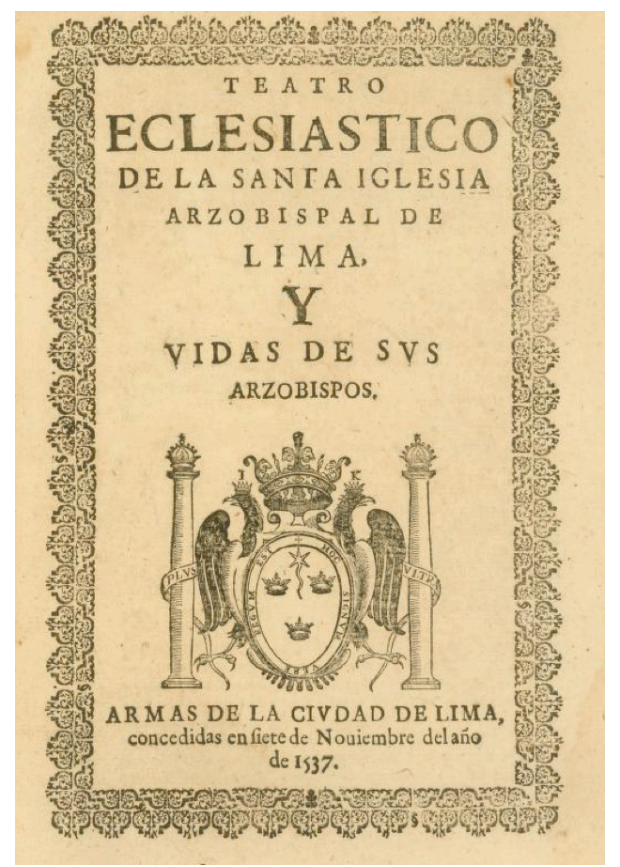

Fonte: Cortesia da Biblioteca John Carter Brown, da Brown University.

Em uma gravura do Teatro eclesiastico de la primitiva Iglesia de las Indias occidentales (figura 3), publicado em Madri, em 1655, constam as colunas de Hércules. Elas estáo presentes na composiçấo das armas da cidade de Lima. A cota de armas foi concedida por Carlos V em 7 de novembro de 1537, como deixa entrever a legenda na gravura. Uma águia bicéfala ostenta um escudo com três coroas, com uma inscrição ao redor: "Hoc signum vere regum est" - "Este é o verdadeiro signo dos reis", os reis católicos. Sobre as cabeças das águias estão assentadas as iniciais de Iona e Karolus - Joana I e Carlos I.

Como destacou Joelson Biltran Trindade, a águia bicéfala foi adotada nos meios eclesiásticos e tornou-se um importante atributo da Monarquia Católica, sendo reapropriada em diversos suportes. ${ }^{15}$ Em comparação com as armas de outras cidades das Índias Ocidentais presentes na mesma obra do cronista Gil Gonzalez Davila, as de Lima são as mais imponentes: fica clara a importância da cidade na hierarquia espacial da América — única a ostentar insígnias imperiais, reforçadas pela presença das colunas de Hércules. Nesta representação de armas, recordada mais de 100 anos após sua instituição, a presença das colunas remete às

\footnotetext{
${ }^{15}$ TRINDADE, Joelson Biltran. O império dos mil anos e a arte do "tempo barroco": a águia bicéfala como emblema da cristandade. Anais do Museu Paulista, São Paulo, v. 18, n. 2, p. 11-91. jul./dez. 2010.
} 
designaçôes imperiais de Carlos $\mathrm{V}$, tấo necessárias a um império fragilizado sob o governo de Filipe IV. Antigos símbolos de poder recuperados em momentos de crise política.

\section{Expansão ultramarina, herói clássico, cultura política}

No Manual compendio de el regio patronato indiano, impresso em Madri no ano de 1755, há uma gravura que possui os elementos até aqui discutidos.

\section{Figura 4}

RIBADENEYRA Y BARRIENTOS, Don Antonio Joaquin de. Manual compendio de el regio patronato indiano. Madri, 1755.

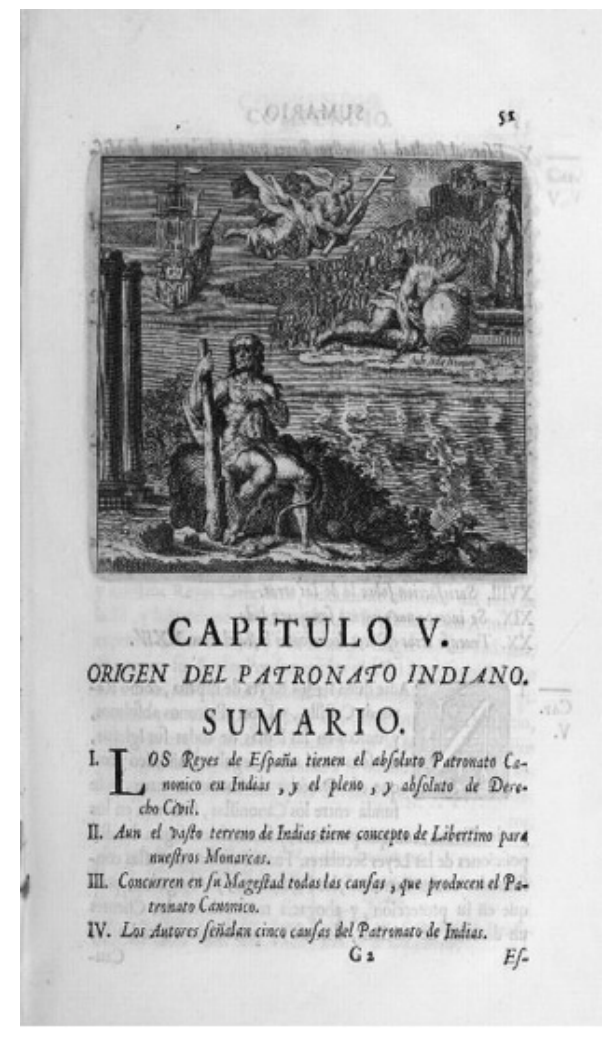

Fonte: Muséum National d'Histoire Naturelle. Cortesia Gallica.

A estampa apresenta dois territórios divididos por águas. De um lado, a alegoria da fé, carregando uma cruz, voa em direção a um indígena que dorme sobre um globo próximo a um ídolo sob um pedestal. Ao fundo de tal imagem encontra-se uma construção arquitetônica com um sol raiando, que faz referência à inscrição em latim abaixo do globo: "sob novo sol". A alegoria da fé está entre o sol e um navio. Na outra margem, sentado sobre uma 
pedra e com uma clava na mão direita, está Hércules. Um pouco mais adiante, à sua direita, estão as duas colunas. Tal gravura ilustra o capítulo V - Origen del patronato indiano -, onde são evocadas realizações para legitimar o patronato espanhol sobre a América. Em um trecho são relembrados os feitos dos reis católicos no início da conquista:

nuestros reys catholicos, santamente movidos del zelo de la Fé, y heroycamente inflamados de la gloria de sus Armas, a expensas de sus thesoros, y de la noble sangre de sus vassallos; plantaron sus Reales Pendones a los pies del sacrosanto lavaro de la cruz, en aquellas ignoradas bastissimas Regiones. ${ }^{16}$

O manual é obra de don Antonio Joaquin de Ribadeneyra y Barrientos, advogado da Real Academia do México. A seleção das estampas não era de sua alçada. Foi escolha de Antonio Marin, impressor em Madri. Para compreender a inserção de um herói clássico em uma gravura sobre patronato indiano no reinado de Fernando VI (1746-1759) é necessário ter em mente que as apropriaçôes de modelos clássicos foram amplas durante a Época Moderna, como demonstrou, por exemplo, Diogo Ramada Curto ao salientar os usos da personagem Apolo pela cultura política filipina. ${ }^{17}$

Na cultura política espanhola do seiscentos, Hércules também foi apropriado para enaltecer os feitos dos governantes, assim como para fornecer um manancial de comportamentos exemplares a serem seguidos pelo rei. Uma destas apropriaçôes do herói pode ser vista na obra de Juan Francisco Fernandes de Heredia - Trabajos y afanes de Hercules —, publicada em Madri, em 1682, e colocada nas mãos do rei Carlos II através de d. Juan Francisco de Lacerda, duque de Medina Celi. ${ }^{18}$ Em um trecho, é feita referência às colunas: "en los extremos del Mundo puso Hercules sus Columnas, pendientes de sus entenas los blasones, y tesoros que llevó à Grecia, no solo de los bienes de fortuna sino los preciosos talentos de las ciencias, haziendose comunes las Artes, y usos artificiosos de muchas provincias." ${ }^{19}$ Heredia é claro ao vincular um dos trabalhos de Hércules à troca mercantil e ao afirmar que o príncipe que desejasse o domínio do mundo deveria fincar um polo na terra e outro no mar. Conselho tardio, pois a Espanha como império entrava em crise. Mas o que importa destacar é que a ideia de uma expansão estava atrelada a um programa político que por sua vez se via vinculado às colunas em sua representação.

Outra função do herói clássico exercida nas gravuras de frontispícios da Monarquia Cató-

${ }^{16}$ RIBADENEYRA Y BARRIENTOS, Don Antonio Joaquin de. Manual compendio de el regio patronato indiano. Madri, 1755. p. 53.

${ }^{17}$ CURTO, Diogo Ramada. Cultura política no tempo dos Filipes (1580-1640). Lisboa: Ediçôes 70, 2011. p. $245-257$.

${ }^{18}$ HEREDIA, Ivan Francisco Fernandes de. Trabajos y afanes de Hercules - floresta de sentencias y exemplos. Madri: por Francisco Sanz, 1682.

${ }^{19}$ Ibid., p. 297. 
lica, como bem destaca Cañizares, era dar combate a Satã e agir como agente "civilizador". ${ }^{20}$ É com esta "missão" que Hércules é apresentado em um detalhe do frontispício de Disputationem indiarum iure (figura 5), publicado em Madri, em 1629, obra de Juan Solozarno Pereira. Em uma obra que versa sobre jurisdição nas Índias houve cuidado em criar um frontispício com uma gravura que projeta uma política imperial, com Filipe IV ao centro dominando os mares e com Hércules dominando uma hidra sobre o apropriado lema Domat omnia virtus (a virtude domestica tudo). $\mathrm{O}$ que melhor para o moral de conquistadores do que um herói mítico e suas histórias exemplares? Como aparece no compêndio de 1755, Hércules visto como um ser pleno de virtudes esteve presente com os espanhóis na colonização de novos territórios e sua iconografia acabou por se vincular à conquista e à administração.

Figura 5

PEREIRA, Solarzano Juan. Disputationem Indiarum Iure. Madri, 1629.

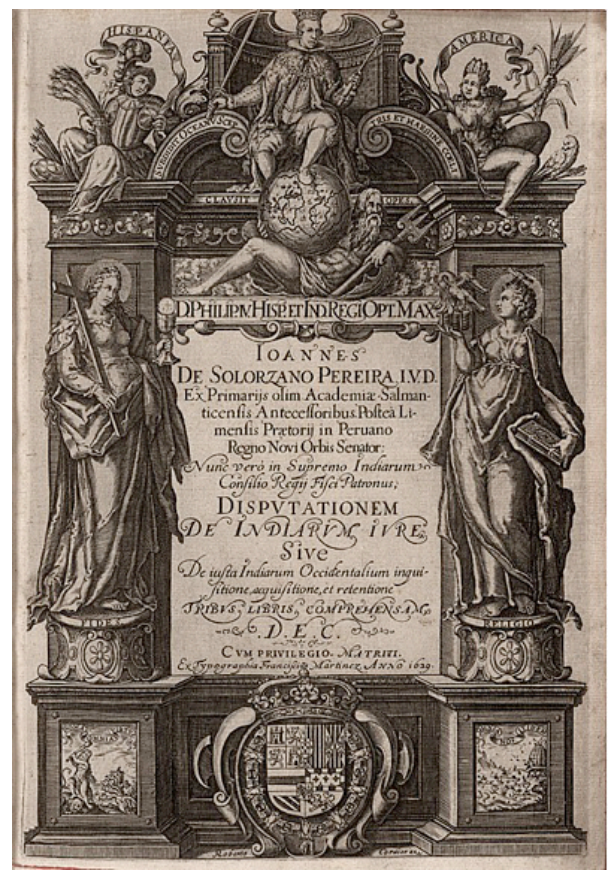

Fonte: Cortesia da Biblioteca John Carter Brown, da Brown University.

Em 1629, o frontispício de Disputationem é uma perfeita representação do poder planetário do monarca espanhol. Filipe IV está com um cetro na mão esquerda e uma espada na direita, seu pé esquerdo se encontra sobre o mundo que é sustentado por Netuno. Ao seu lado direito encontra-se a alegoria da Hispania, da maneira como a representavam os romanos, com a armadura de uma guerreira e segurando um feixe de espigas de trigo, símbolo da

${ }^{20}$ CAÑIZARES-ESGUERRA, Jorge. Católicos y puritanos en la colonización de América, op. cit. p. 60-64. 
fertilidade. Do lado esquerdo do rei está a alegoria da América, com uma espiga de milho nas mãos, um arco e flecha e um papagaio. A espécie de trono arquitetônico em que o rei se assenta possui a inscrição Subdidit oceanu sceptris et margine coeli clausit opes, frase retirada do panegírico que o poeta Claudiano (c. 370-404) fez a Honorio: "subjugou o oceano para seu governo e definiu o céu de fronteira para o seu reino". As colunas que sustentam a estrutura são ornadas com as alegorias da fé — lado direito de Filipe IV — e da religião — lado esquerdo do rei. Como colunas, essas figuraçôes representam a força do império.

No discurso da dedicatória feita ao rei, empreendido por Juan de Solorzano Pereira, a imagem de um monarca que governa uma considerável parte do mundo é reforçada. Solorzano, que foi auditor da Audiencia de Lima entre 1610 e 1627, se refere à Espanha como "um dilatado Império", a "monarquia mais dilatada que se viu no mundo". Em todo enunciado, Solorzano destaca a grandeza do Império, recorrendo a textos clássicos e modernos. O lema plus ultra une todas as tópicas e vincula não somente o Novo Mundo ao Velho, mas também diferentes temporalidades.

\section{Plus ultra: conhecimento do mundo}

Como salientamos, o mote plus ultra estava intrinsecamente vinculado às colunas de Hércules, desde o reinado de Carlos V, denotando uma perspectiva imperial. Essa perspectiva está na justificativa do frontispício de uma obra sobre a guerra dada aos holandeses no Brasil:

E porque na estampa que faz rosto ao nosso argumento, parecera menos vulgar a letra Qua non patet orbis, adverte-se que o Conde João Mauricio de Nassau, sendo o General do Brasil das armas holandesas trazia por empresa nas suas (como ainda se vê em todas as obras publicas dos anos que governou as capitanias do Norte; tão ostentosamente escritos, na avultada historia de Gaspar Barleu) Qua patet orbis [grosso modo "Até onde houver mundo"]. Pelo que, (deixando as circunstâncias que os leitores por si mesmos alcançarão facilmente) acrescentamos ao mote do Conde, o non, que o imperador Carlos Quinto, tirou ao non plus ultra das colunas de Hércules. A que as antigas naus insoluvelmente prenderam tantos séculos as amarras: que rotas pela feliz ousadia dos portugueses dilataram o Universo com terras incógnitas, por mares nâo sulcados. $^{21}$

\footnotetext{
${ }^{21}$ FREYRE, Francisco de Brito. Nova Lusitânia: história da guerra brasílica. Lisboa, 1675. b. 3.
} 
Figura 6

FREYRE, Francisco de Brito. Nova Lusitânia: história da guerra brasílica. Lisboa, 1675.

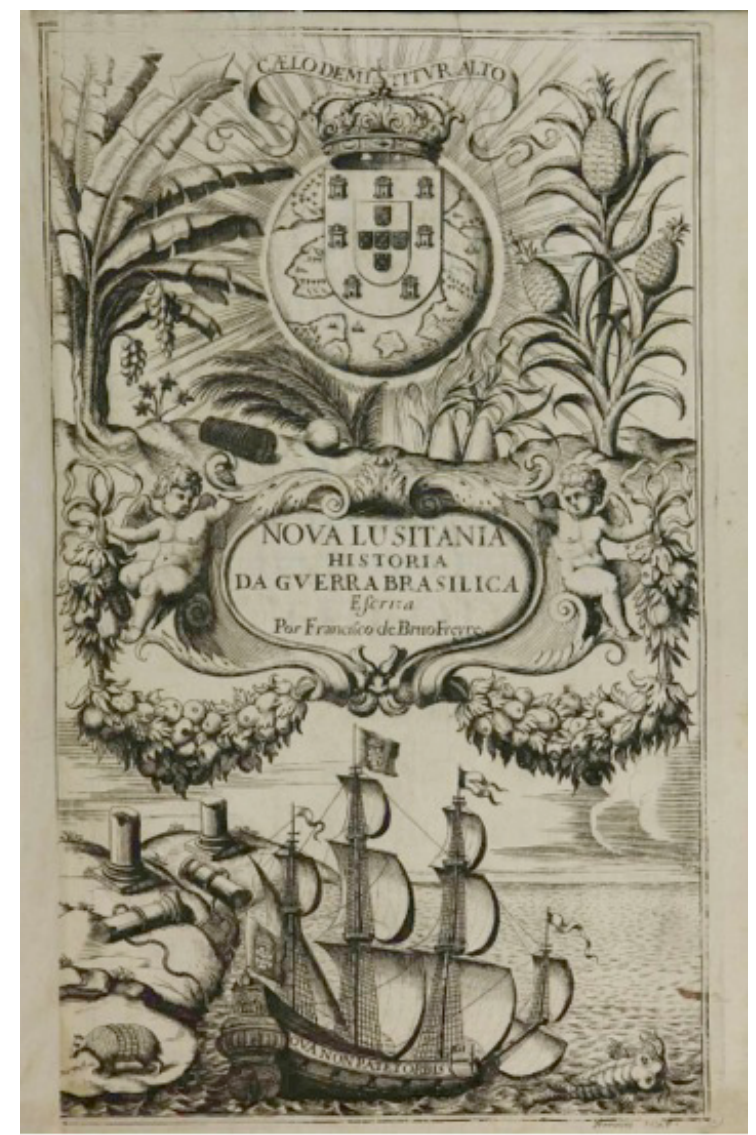

Fonte: Cortesia da Biblioteca Brasiliana Guita e José Mindlin-USP.

Em referência a imagens, poucas vezes é possível ler uma explicação como a que foi realizada por Francisco de Brito Freyre na advertência da obra de 1675 (figura 6). Apesar do crédito concedido a Carlos V, Freyre relaciona as colunas de Hércules ao "dilatamento universal” empreendido não pelos espanhóis, mas sim pelos portugueses. A apropriação iconográfica operada na Nova Lusitânia: história da guerra brasílica e a operação de deslocamento da partícula non demonstram que o repertório simbólico não era algo estático e vinculado apenas a determinada cultura política, estando aberto ao universo ibérico.

No caso em particular há ainda espaço para uma ambiguidade, pois as colunas de Hércules foram gravadas de uma maneira que não aparecem em nenhuma outra gravura do período: partidas, em ruínas, e com as amarras ligadas a uma embarcação. No frontispício gravado pelo francês Jean Bérain, o Velho (1637-1711), as ruínas das colunas são, como expóe Freyre, uma referência à libertação das amarras, no sentido de plus ultra, mas também uma referência, pós-Restauração portuguesa, ao fim do jugo do império espanhol sobre 
Portugal, já que tais colunas possuíam intrínseca vinculação à Espanha e a seus domínios e o autor conhecia tal relação. De qualquer forma, esse frontispício aponta como o dispositivo formado por colunas, navegação e o mote plus ultra não era uma exclusividade dos espanhóis e muito menos possuía apenas um sentido.

Figura 7

Epitome de la biblioteca oriental y ocidental, náutica y geográfica. Madri, 1629.

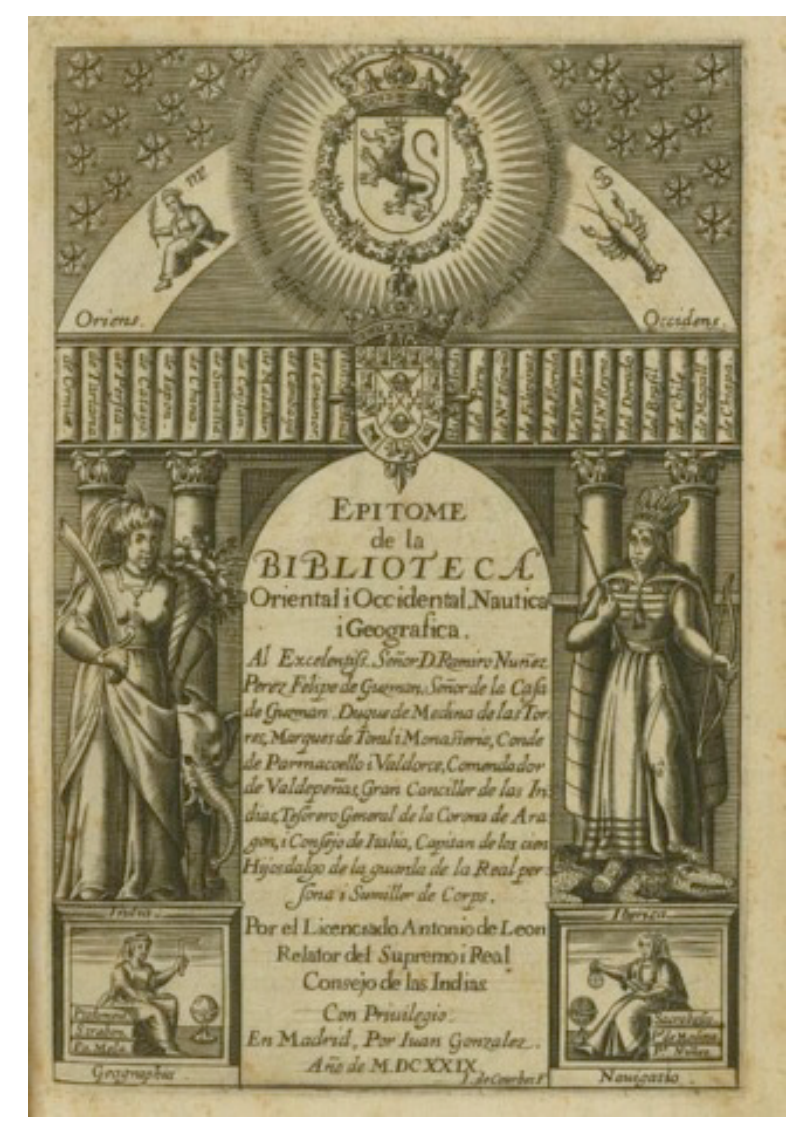

Fonte: Cortesia da Biblioteca John Carter Brown, da Brown University.

No século XVII, navegação e conhecimento consolidavam-se na concepção de plus ultra, e entre os espanhóis foi vulgarizado por meio de gravuras. Equidistantes territórios da monarquia, conhecimento, navegaçáo e ideia de plus ultra fazem parte de um repertório que encontramos na página de rosto da Epitome de la biblioteca oriental y ocidental, náutica y geográfica (figura 7), publicada no ano de 1629, em Madri. A gravura produzida por Juan de Courbes, gravador de origem francesa, adorna o frontispício da obra do licenciado Antonio de León Pinelo, um catálogo com mais de 400 obras referentes aos domínios no ultramar. A iconografia é bastante complexa, com diversos elementos dispostos. Encimando a gravura 
está um símbolo da realeza espanhola: um leão coroado. Atrás dele há um sol com frase retirada do Eclesiastes 42: "O sol contempla todas as coisas que ilumina; a obra do senhor está cheia de sua glória”. Passando pelo sol, uma faixa cruza o céu estrelado, no lado esquerdo, indicado por Oriens, está uma representação do signo zodiacal de Virgem, enquanto o outro extremo, Occidens, ostenta o signo de Câncer. Logo abaixo deste arco com os dois extremos do mundo, uma fileira de 24 livros está disposta como se estivesse em uma estante de biblioteca, e apresenta obras que tratam de terras distantes da Espanha, mas com alguma vinculação ao império. Em suas lombadas, podem se ler os nomes de lugares como Ormuz, China e Camboja, no lado oriental; Peru, Nova Espanha, Florida e Brasil no lado ocidental. Essa disposição indica a abrangência das conexôes planetárias do império, ou pelo menos a imagem que foi cunhada durante as conquistas de territórios além-mar a partir de vivências de viajantes. É destacável a busca por uma unidade, assunto tão em conta na política hispânica seiscentista.

As duas colunas que sustentam a dita biblioteca estão ornadas com alegorias da Índia, representada com atributos alegóricos da Ásia, e da Ibérica, com atributos da alegoria da América. Pinelo afirma que "América" é um termo errôneo, pois não tem a precisão do termo "Ibérica" que indica regióes conquistadas por portugueses e espanhóis; talvez por isso ela não esteja representada com os atributos que a caracterizam como uma selvagem: a nudez e as cenas de canibalismo. Na base de tais colunas há outras alegorias: geografia, abaixo da Índia, e navegação, abaixo da Ibérica. Enquanto a representação da geografia está sentada sobre os livros de Ptolomeu, Estrabão e Pomponio Mela, geógrafos, matemáticos e astrônomos da antiguidade clássica, a alegoria da navegação se apoia em obras de Juan de Sacrobosco, inglês que escreveu um tratado sobre a esfera em 1220; de Pedro de Medina, cosmógrafo real de Espanha e autor de Arte de navegar (1545); e do português Pedro de Nunez, matemático e geógrafo quinhentista. É perceptível a divisão entre "antigos" e "modernos". Por sua totalidade, o frontispício da obra de Pinelo apresenta a abertura do mundo empreendida pelo conhecimento.

Antonio Pinelo, filho de judeus portugueses, chegou ao rio da Prata em 1604 juntamente com seus irmãos. Residiu ainda em Córdoba, Lima e Buenos Aires, antes de retornar à Espanha no começo da década de 1620. Por conta de seu letramento e experiência, Pinelo ocupou postos no Conselho de Índias, chegando a ser cronista mayor de Indias entre $1658 \mathrm{e}$ 1659. Antes disso, como relator do Conselho publicou, em 1630, o Tratado de confirmaciones reales de encomiendas, oficios y casos en que se requieren para las Indias Occidentales (figura 8), importante instrumento jurídico para referência de privilégios. A gravura do frontispício também foi realizada por Juan de Courbes. Se na Epitome de la Biblioteca há uma alegoria da Índia e da Ibérica, neste há uma alegoria do Peru e da Nova Hispania como colunas que sustentam o império. 
Figura 8

PINELO, Antonio de León. Tratado de confirmaciones reales de encomiendas, oficios y casos en que se requieren para las Indias Occidentales. Madri, 1630.

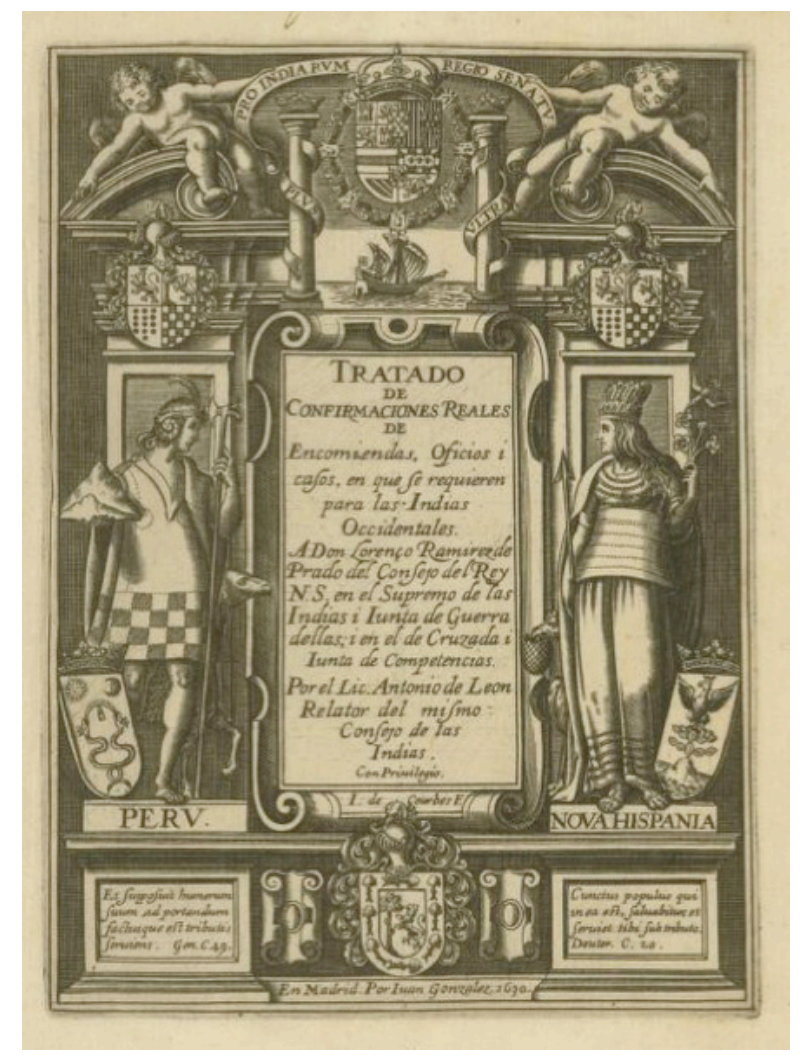

Fonte: Cortesia da Biblioteca John Carter Brown, da Brown University.

No prólogo escrito por Juan Rodrigues de León, irmão de Antonio, há indícios preciosos para reflexão sobre o uso de gravuras em frontispícios e o estatuto de representação. Segundo Juan, o frontispício ensina grande lição "tanto en apropriar la pintura a la obra, como en retratar lo imitado con la propriedad". $22 \mathrm{O}$ que seria este "imitado" senão a própria universalidade empreendida pelo império espanhol? Juan destaca que há conveniência na apropriação das colunas de Hércules, do mote plus ultra e da embarcação, elementos que encimam a gravura. As duas coroas sobre as colunas de Hércules são explicadas da seguinte maneira: "Las coronas imperiales significan duplicado el imperio español con el descubrimiento del Mundo Nuevo". ${ }^{23}$ As observações de Juan não param por aí, pois ele descreve os dois índios que servem como colunas: um índio representando o reino do Peru e uma índia representando o México. Diferentemente das representações geográficas que enfocavam os continentes como alegorias,

\footnotetext{
${ }^{22}$ PINELO, Antonio de León. Tratado de confirmaciones reales de encomiendas, oficios y casos en que se requieren para las Indias Occidentales. Madri, 1630. Prólogo não paginado.

${ }^{23}$ Ibid.
} 
no frontispício em questão regiôes mais específicas da América hispânica ganham sua própria representação, não obstante inserirem-se em uma perspectiva mais ampla, como salienta o conjunto de atributos acima de toda a gravura.

Esta relação global/local no uso do mote plus ultra integrado à alegoria de uma regiáo é também encontrada no frontispício do Memorial discursivo sobre el oficio de protector general de los indios del Piru (figura 9), obra impressa em Madri no ano de 1626, por Juan Lanirraga Salazar, cavaleiro do Hábito de Santiago.

Figura 9

\section{SALAZAR, Juan Lanirraga. Memorial discursivo sobre el oficio de protector general de los indios del Piru. Madri, 1626.}

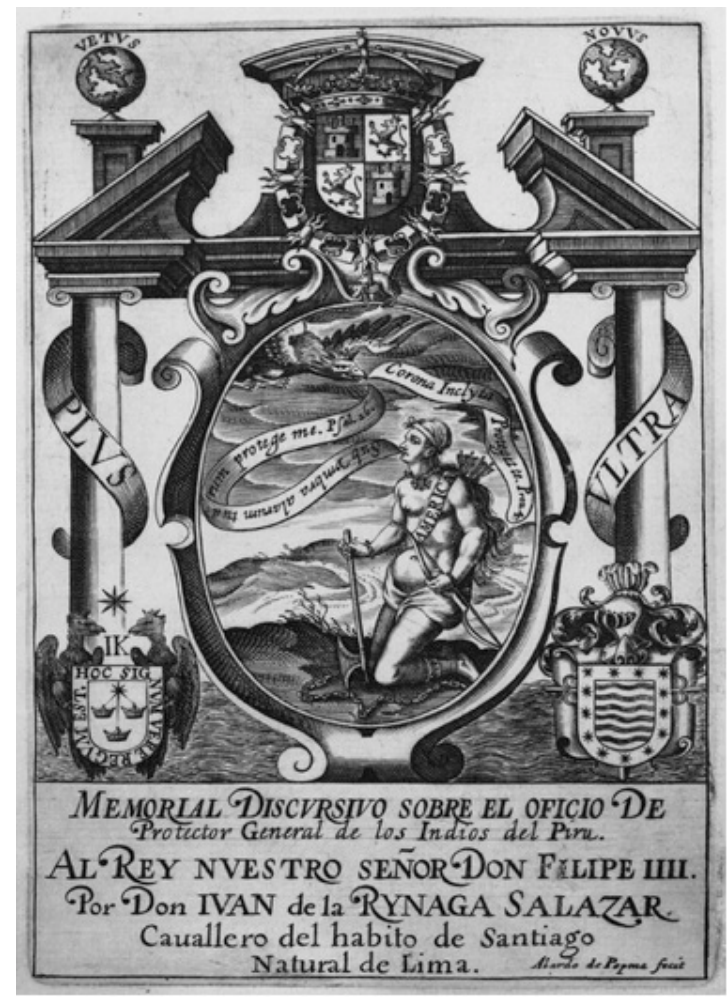

Fonte: Cortesia da Biblioteca John Carter Brown, da Brown University.

O ofício de protetor dos índios foi criado em 1516 com a nomeação de frey Bartolomé de las Casas como "procurador y protector universal de todos los indios". Verificando possíveis maus-tratos aos nativos, o ocupante de tal ofício deveria zelar juridicamente pelos índios entáo enquadrados no estatuto de "miseráveis". Tal tutela pode ser decodificada no frontispício realizado pelo gravador natural de Flandres, Alardo Popma. Emoldurada por duas colunas que levam o mote plus ultra há um rocaille oval que dentro possui a iconografia de uma índia ajoelhada — trata-se da América, como deixa claro a faixa que sustenta —, há também uma 
águia com uma Coroa. Entre a índia com grilhôes e a águia ocorre um dialogo através de inscriçôes em legendas. De sua boca saem os dizeres "Sub Vmbra alarum tua rum prote me. Psal. 26" (Proteja-me à sombra de tuas asas). Enquanto a águia coroada emite a mensagem: "Corona Inclyta proteget te. Prov. 4" (Coroa nobre irá protegê-lo). A reciprocidade entre a Coroa espanhola e seus súditos em terras além-mar é estampada com uso da síntese de passagens bíblicas que tratam de proteção e subserviência. Acima das colunas há dois globos, um possui a inscriçáo vetus, e o outro novus, lembrando os espaços sob domínio da monarquia representada no tímpano por seu símbolo máximo, sua cota de armas. A arquitetura formada pelas colunas e o frontão é a representaçáo de um espaço amplo, e a inclusão da América nesse espaço se dá por meio de uma reciprocidade.

O modelo desse frontáo pode ser encontrado em uma gravura que o citado Juan de Courbes fez para o frontispício de Historia verdadera de la conquista de la Nueva España (figura 10), obra do capitão Bernal Diaz del Castillho (1496-1584), um dos conquistadores do novo território. Em vez de uma índia, Courbes inseriu um globo com a América em destaque, abaixo dele há uma faixa com a palavra condita (foi fundada). Regiáo fundada pela ação (Manu) de conquistadores como Cortez e pela palavra catequética (Ore) de religiosos como frei Bartolomeu de Olmedo, ambos representados como duas colunas, um à esquerda e outro à direita, e acima de um medalhão com a representaçáo do México.

\section{Figura 10}

\section{DEL CASTILHO, Bernal Diaz. Historia verdadera de la conquista de la Nueva España. Madri, 1632.}

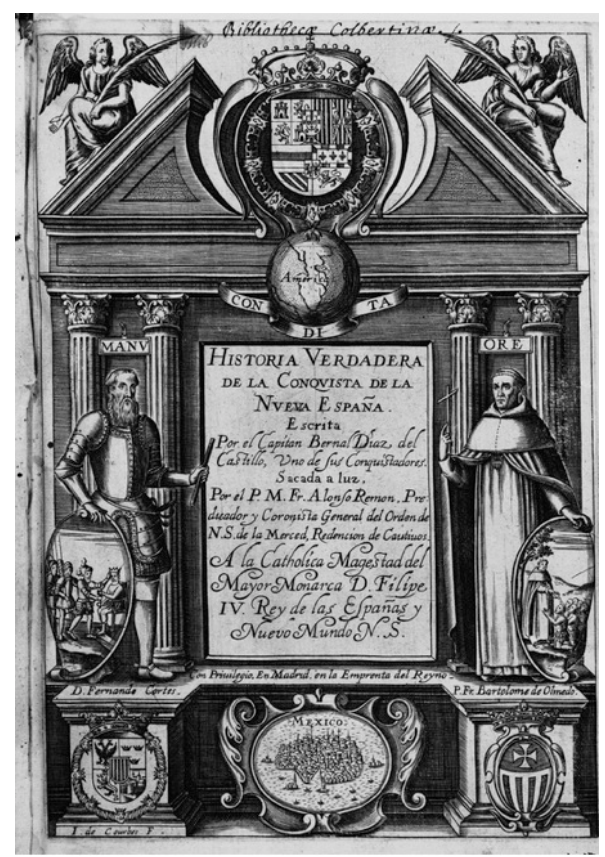

Fonte: Cortesia da Biblioteca John Carter Brown, da Brown University. 
A historiadora María del Carmen León Cázares destaca que nessa obra houve uma interpolación mercedaria já que existiu, durante o processo editorial, uma clara intencionalidade por parte dos mercedários em ampliar os feitos de seus irmáos de hábito. ${ }^{24}$ Acreditamos que a parte primeira e mais visível dessa interpolación está no próprio frontispício: enquanto Cortéz segura um escudo que tem a representação de um de seus maiores feitos - a captura de Monteczuma -, frei Bartolomé em seu escudo é representado batizando muitos nativos de joelhos. Os dois feitos da conquista se igualam por conta da simetria sugerida pelas posiçóes dos dois personagens.

No reinado de Filipe IV, os frades mercedários invocaram uma memória interpolada inserindo a Ordem na própria fundação da Nova Espanha. Na disputa por precedência que assolou a Europa moderna, esta náo foi a única ordem religiosa a utilizar esta estratégia de vincular-se a fundação de novos territórios e muito menos a ativar um dispositivo de memória das origens de sua missionação na América, usando largamente as gravuras para cunhar imagens dessa inserção. Tampouco, entre os religiosos, a crônica foi o único gênero a receber tal iconografia em sua folha de rosto. Biografias de religiosos também eram espaços agraciados com iconografias vinculadas à mundialização empreendida pelo Império.

No frontispício de Fama y obras posthumas del fenix de Mexico, décima musa, poetisa americana, sor Juana Ines de la Cruz, publicado em Madri, em 1700, há uma referência iconográfica que amalgama o mote plus ultra e as alegorias da América e da Europa (figura 11). Essa obra é fruto dos esforços de d. Juan Ignacio de Castonera, prebendário de Igreja Metropolitana do México, que organizou poemas da religiosa professa no Convento de San Geronimo, conhecida como uma das maiores escritoras seiscentistas. As obras reunidas de soror Juana foram dedicadas à rainha Mariana, mulher de Carlos II, e também à marquesa del Valle de Oaxaca, d. Juana de Aragon Y Cortez.

Para uma compreensão mais aproximada da significância da gravura em um frontispício, pelo menos na cultura visual seiscentista, é relevante dar atenção ao que dizem os agentes do período: "El dibuxo de su lamina se expresa mas doctamente la fisonomia del alma, que es la viveza del pensamiento, en lo alusivo de sus emblemas". ${ }^{25} \mathrm{~A}$ imagem representava também as próprias ideias, os valores, o intangível. D. Juan explica que os dois escudos presentes acima e abaixo da gravura sáo respectivamente os escudos da rainha e da marquesa del Valle. Ainda de acordo com o compilador, os anjos que aparecem acima de cada coluna possuem a funçáo de coroar e de publicar (tornar público, dar fama). Os anjos são então vinculados ao México, lugar que coroou soror Juana, e a Madri, lugar que lhe dá fama ao publicar suas obras. Os atributos que se encontram espalhados na parte inferior da gravura também mereceram atenção no prólogo: "Los instrumentos estudiosos, espheras, mapas, astrolabios, tubos ópticos,

\footnotetext{
${ }^{24}$ LEÓN CÁZARES, María del Carmen. Reforma o extinción: un siglo de adaptaciones de la Orden de Nuestra Señora de la Merced en Nueva Espańa. México: Unam, 2004. p. 210-232.

${ }^{25}$ Fama y obras posthumas del fenix de Mexico, décima musa, poetisa americana, sor Juana Ines de la Cruz. Madri, 1700. p. 121.
} 
triorbas, cytaras, Compas, plumas y libros, simbolizam su aplicacion a todas artes, y sciencias" ${ }^{26}$ Por fim, com as figuras femininas que estáo à direita e à esquerda do retrato de soror Juana, d. Juan vincula diversos elementos que discutimos até o momento, ressaltando o sentido imperial da iconografia realizada por Joseph Caldevilla e Clemens Puche: "Los dos simulacros en dos columnas, con el ultra plus, que difundió en margenes segunda Minerva la Poetisa, y adelantó en Imperios el siempre heroyco Cortés, Hercules segundo al termino del otro Non Plus Ultra, significan Europa y America". ${ }^{27}$

Figura 11

Fama y obras posthumas del fenix de Mexico, décima musa, poetisa americana, sor Juana Ines de la Cruz. Madri, 1700.

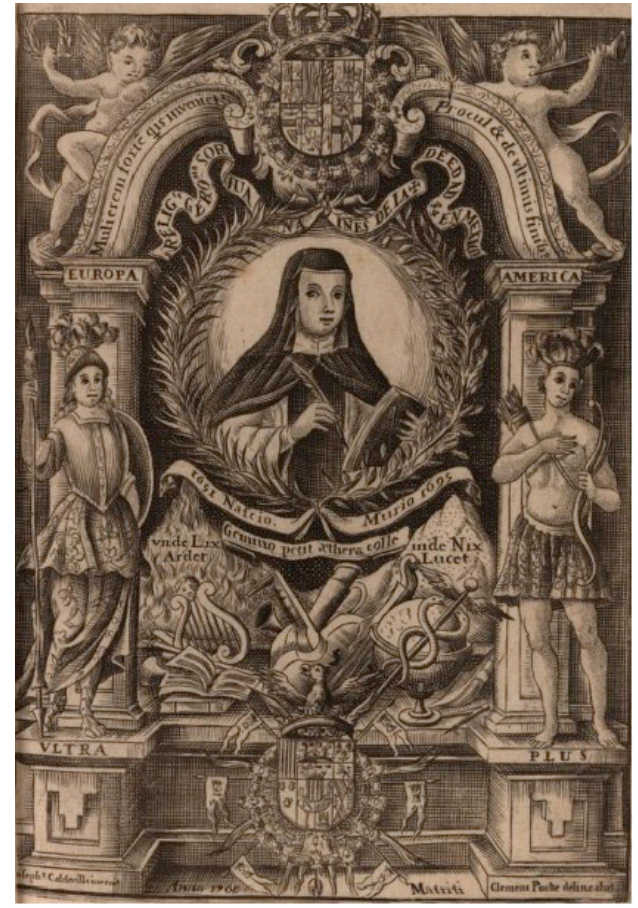

Fonte: Cortesia da Biblioteca John Carter Brown, da Brown University.

Com a inscrição ultra a seus pés, Europa é representada de maneira distinta da alegoria mais comumente encontrada em diversas gravuras do século XVII e vulgarizada a partir de imagens como a de Cesare Ripa, onde é uma rainha, cercada de cetros, grinaldas e coroas, pois fora considerada "a parte principal do mundo". No frontispício em questão, Europa é uma guerreira, com lança e escudo, atributos que possui a figura impetuosa pintada por Ticiano (1486-1575) para personificar a Espanha no socorro à fé católica, em um quadro

\footnotetext{
${ }^{26}$ Ibid., p. 123

${ }^{27}$ Ibid., p. 122.
} 
que hoje se encontra no Museu do Prado, ou também, o que é muito coerente pelo que é citado no prólogo, é semelhante à representação da deusa Minerva. De acordo com d. Juan, a inscrição em latim acima da coluna é uma pergunta que sai da boca desta Europa guerreira, que possui também um elmo e uma armadura: "Mulierem fortem, quis inveniet?" (Uma mulher forte, quem achará?); ao que na outra extremidade, a América - uma índia, como comumente foi representada no século XVII - também pergunta: "Procul, e de ultimis sinibus?" (À distância, dos mais remotos recantos?). Todavia, essa índia não é representada com as características da selvageria. Seu gesto com a mão direita ao peito e seu olhar são de contrição. Uma descrição apropriada ao conjunto geral da imagem.

Soror Juana, considerada "mulher forte" mesmo por seus contemporâneos, filha de uma criolla e um militar espanhol, é emoldurada pelos dois "simulacros" da Europa e da América. Seu retrato ao centro, como uma mulher de letras, empunhando uma pena e um livro, enuncia não somente os valores de uma religiosa erudita, mas sobretudo, resultados positivos da expansão ultramarina personificados em uma mulher rodeada por atributos de um império amplo.

\section{Expansão católica, “verdadeiro” Hércules}

O frontispício da obra La conveniencia de las dos monarquias catolicas, la de la precedencia de los reyes catolicos de España a todos los reyes del mundo, publicada em Madri, em 1612, apresenta as alegorias de Roma e da Espanha apoiando um globo ao centro (figura 12). Acima do globo, as armas papais e as da monarquia hispânica estão entrelaçadas e com a inscrição retirada do Gênesis: fecit deus luminaria magna (Deus fez dois grandes luzeiros). $\mathrm{Na}$ dedicatória, no próprio frontispício, a referência a Filipe III salienta a extensão de seus domínios, complementando a iconografia: "Al Gloriosisimo Filipo Ermenigildo nuestro señor Emperador de las Españas y Señor de la Maior Monarquia que antenido los hombres desde la creoación hasta el Siglo presente".

Não obstante a eloquência do frontispício, o autor frey Juan de la Puente explica a construção de sua retórica visual em "Declaracion del blason que esta en la cabeça deste libro". ${ }^{28}$ Seus leitores necessitavam de um reforço para o melhor entendimento dos elementos iconográficos expostos, ou necessitavam mesmo de uma explicaçáo para entendimento de toda a gravura. Fato é que frey Juan afirma a importância da representaçáo em um frontispício, considerando-a um epílogo para todo o seu intento.

\footnotetext{
${ }^{28}$ LA PUENTE, Juan de, frey. La conveniencia de las dos monarquias catolicas, la de la precedencia de los reyes catolicos de España a todos los Reyes del Mundo. Madri, 1612. p. XXII.
} 
Figura 12

LA PUENTE, Juan de, frey. La conveniencia de las dos monarquias catolicas, la de la precedencia de los reyes catolicos de España a todos los reyes del mundo. Madri, 1612.

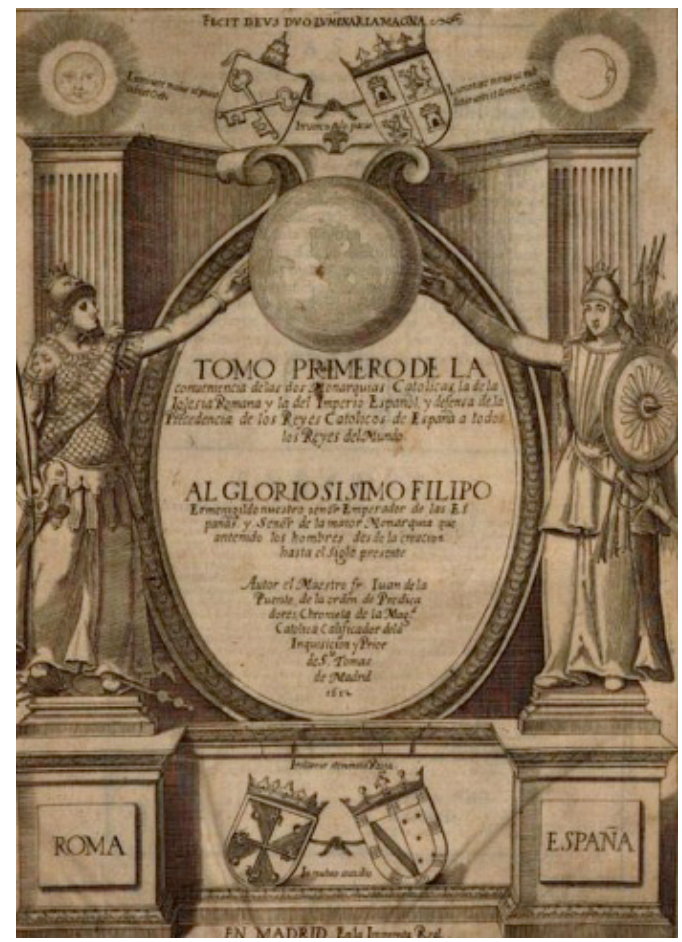

Fonte: Biblioteca Estadual da Baviera.

Sobre as duas grandes luminárias citadas na inscrição em latim, frey Juan informa que se trata da Lua e do Sol colocados acima de colunas. Entretanto, na imagem retórica, os astros não são exatamente o que parecem: "El sol es simbolo de la potestad espiritual que reside en el Papa, y la Luna símbolo de la potencia temporal del mayor de los Reys". O frade apresenta a disposição dos elementos para o entrelaçamento do campo espiritual e temporal: "Siguiendo esta alegoria, pongo junto al sol las armas del Pontifice Romano, cabeça de la Iglesia Universal, y junto a la Luna el escudo del Rey nuestro señor, Monarca del Imperio Español". Entre o Sol e o escudo da Igreja foi posta uma inscrição em latim, que frey Juan traduz da seguinte forma: "La lumbrera mayor para que presida en la ciudad y en el mundo". E entre a Lua e o escudo do rei: "La lumbrera menor, para que obedezca a la ciudad y sea señora del mundo". A relação hierárquica é clara, todavia, o religioso fez questão de salientar que: "los dos escudos enlazados, $y$ inclinados el uno hazia el otro, significan el amor y unidad que siempre an conservado entre si las dos Monarquias Catolicas" ${ }^{29}$

Ao definir a mulher de hábito grave como Roma, "cabeça da monarquia eclesiástica”, e

${ }^{29}$ Ibid. 
a Espanha como uma guerreira, da maneira como a pintavam os antigos, como "cabeça da Monarquia Católica”, a explicação dada para as alegorias das monarquias se completa. A dimensão espacial do império, algo que é constantemente lembrado pelo religioso, é então destacada: "Estan sustentando el Mundo, porque la mayor parte del está sujeta a la potestad espiritual del Papa, y a la temporal de la majestad Catolica, sin que haya otra potencia que le exceda, ni aun le yguale" ${ }^{30} \mathrm{O}$ uso da descriptio em um elemento paratextual apenas reforça o caráter alegórico do frontispício como um todo, já que era dessa forma, imagem somada a sua descrição, que os livros de alegorias e de emblemas eram formados na Época Moderna. ${ }^{31}$

A ideia de uma expansão - como bem expressa no frontispício de De la conveniencia... - é muito cara à Igreja Católica desde seus primórdios, talvez sendo mesmo uma de suas principais características. Entretanto, na concepção pós-tridentina, no contexto de exploração de novos territórios além-mar, a expansão da fé tomou direcionamento que ia ao encontro de projetos de dinâmica imperial. ${ }^{32}$

No mesmo contexto, o clero regular, partícipe constante deste processo, foi responsável pela produção de rotinas historiográficas que visavam, sobretudo, registrar a memória desta inserção, recriando gêneros - crônicas de conventos, história da fundação de províncias, memórias de missionários e hagiografias - que buscaram validar sua presença em várias regióes. Nas disputas entre as ordens religiosas sobressaíam justificativas que tinham por base a preeminência de suas casas em determinado território. As obras em questão serviam para reforçar valores acionados durante as tensôes eclesiásticas: antiguidade, extensão da missionação, santidade dos membros da ordem.

A Companhia de Jesus, ordem conhecida pela extensão de suas missóes, concomitantemente com a expansão marítima empreendida pelos ibéricos na Época Moderna, construiu uma retórica que valorizava a dilataçáo de seus empreendimentos pelos quatro cantos do mundo. Tal retórica é encontrada no frontispício de Historia de la provincia de la Compañia de Jesus de Nueva España, escrita pelo padre Francisco de Florencia e publicada no México em 1694 (figura 13). Nele, Inácio de Loyola está sob meio globo e de seu peito, onde se encontra o símbolo da Companhia, partem dois fachos de luz que iluminam os peitos de outros dois religiosos que, por conseguinte, iluminam os súditos que estâo de joelhos logo abaixo.

\footnotetext{
${ }^{30}$ Ibid., p. XXIII.

${ }^{31}$ HANSEN, João Adolfo. Alegoria: construção e interpretação da metáfora. São Paulo: Atual, 1986.

${ }^{32}$ RAMINELLI, Ronald. Império da fé: ensaio sobre os portugueses no Congo, Brasil e Japão. In: FRAGOSO, João; BICALHO, Maria Fernanda; GOUVÊA, Maria de Fátima (Org.). O Antigo Regime nos trópicos: a dinâmica imperial portuguesa (séculos XVI-XVIII). Rio de Janeiro: Civilização Brasileira, 2001. p. 225-247.
} 
Figura 13

FLORENCIA, Francisco de. Historia de la provincia de la

Compañia de Jesus de Nueva España. Mexico, 1694.

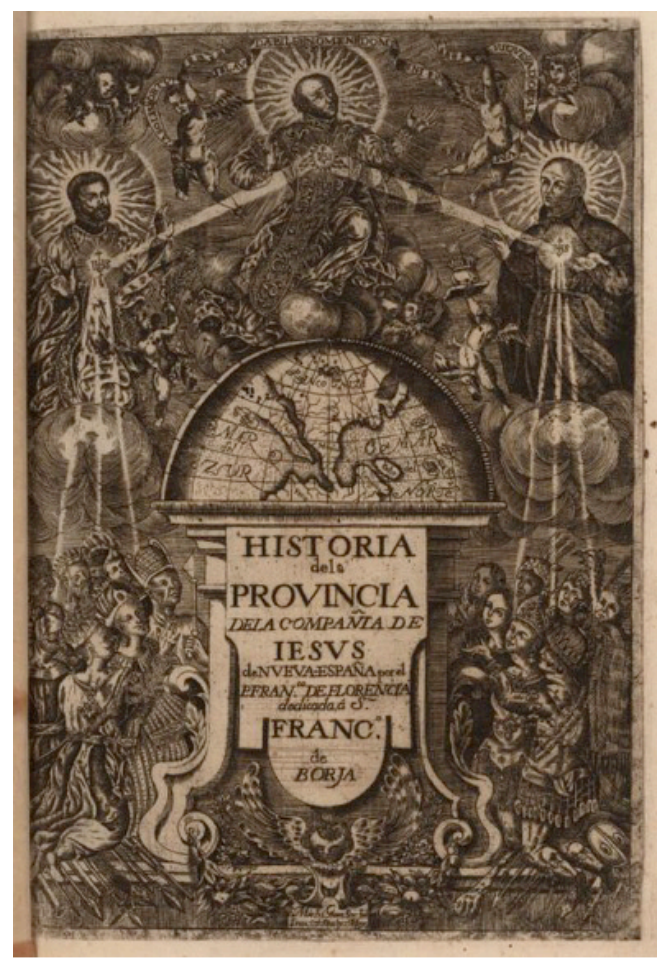

Fonte: Cortesia da Biblioteca John Carter Brown, da Brown University.

No início da dedicatória ao padre são Francisco Borja, o autor lembra os feitos de Hércules ao alargar os domínios do mundo até sua chegada a "Espanha". Entretanto, e aqui há uma clara referência à gravura do frontispício, o herói mítico é considerado "fingido", sendo o verdadeiro Hércules o fundador da Companhia: Loyola.

La verdad de esta Historia, ó la alma de esta fabula, fue verdad en la Historia de los prodigiosos descubrimientos de las regiones de Oriente, Japon y China: de las provincias de Occidente, y NuevaEspaña, en que parece se vió verificado el Plus ultra, que al Non Plus Ultra, de el fingido Hercules, contrapuso el Hercules verdadero de España, el prodigioso Alcides de la Santidad; el Cantabro Heroyco S. Ignacio de Loyla, Fundador de la Compañia de Jesus; que acabados los terminos de el mundo levanto en los Montes de España, dos columnas de Santidad, que fueron los dos Franciscos, Xavier y Borja. ${ }^{33}$

\footnotetext{
${ }^{33}$ FLORENCIA, Francisco de. Historia de la provincia de la Compañia de Jesus de Nueva España. Mexico, 1694. p. XI.
} 
Os jesuítas foram peritos em forjar imagens elogiosas para seus membros, sobretudo mediante o discurso alegórico. ${ }^{34} \mathrm{O}$ enunciado expóe que dois religiosos que estão no frontispício - são Francisco Xavier, do lado direito, e são Francisco Borja, do lado esquerdo são como as duas colunas de Hércules, pois cobrem extensóes amplas, o Oriente no caso do primeiro e o Ocidente no segundo, como salientado pelos aspectos e atributos dos súditos de joelhos: chefes ameríndios de um lado e reis orientais do outro. Fundem-se em uma única iconografia a expansão do império espanhol e a expansão da ordem religiosa, mesmo que o livro em questão abarque apenas uma região específica - a Nova Espanha. Nessa representação, não ocorre a mesma situação da mudança de Hércules carregando um javali no século III, em Veneza, para uma alegoria da Salvação no século XIII, descrita por Panofsky como exemplo do domínio da temática pagã por ideias cristâs. ${ }^{35}$ Não há persistência na forma pois Hércules não aparece personificado da maneira clássica no frontispício, tampouco suas colunas surgem como monumentos, como demonstrei em outros frontispícios. Ocorre, sim, uma interessante operação de analogia por conta da personificação, denotando a persistência das colunas de Hércules como imagem significativa da universalidade de um império ou mesmo de uma ordem religiosa. Tal operação demonstra a relevância simbólica de modelos clássicos para apresentaçáo de uma investida imperial.

Acreditamos, de acordo com imagens que analisamos em diversos acervos, que esta estratégia foi uma constante na monarquia católica, ressaltando visualmente o vínculo entre a Igreja militante e a expansão ibérica, algo bem expresso por Charles Boxer nos estudos sobre a atuação do clero nos quatro cantos do mundo, mas pouco explorado em pesquisas que tenham imagens como fontes. ${ }^{36}$

\section{Histórias conectadas, imagens que se conectam}

As colunas indicam os vínculos planetários, por conseguinte, histórias também. ${ }^{37} \mathrm{~A}$ persistência de imagens que representam as conexôes entre espaços separados pelo Atlântico foi registrada na exposição que o Museo Reina Sofia, em Madri, promoveu com o título Principio Potosi. ${ }^{38}$ Ao adentrá-la em 2010, o visitante pôde refletir sobre a conotação política da re-

\footnotetext{
${ }^{34}$ PRAZ, Mario. Imágenes del barroco. Estudios de emblemática. Madri: Ediciones Siruela, 2005. p. 205.

${ }^{35}$ PANOFSKY, Erwin. Significado das artes visuais. São Paulo: Perspectiva, 2002. p. 66-67.

${ }^{36}$ BOXER, Charles R. A Igreja militante e a Expansão Ibérica, 1440-1770. São Paulo: Companhia das Letras, 2007.

${ }^{37}$ A monarquia católica é um excelente ponto de referência para estudos que abarcam histórias conectadas, como bem demonstrou Serge Gruzinski. GRUZINSKI, Serge. Os mundos misturados da monarquia católica e outras connected histories. Topoi. Revista de História do Programa de Pós-graduação em História Social da UFRJ, Rio de Janeiro, v. 2, p. 175-195, 2001.

38 Disponível em: <http://potosiprincipleprocess.files.wordpress.com/2011/11/principio-potosc3ad-catc3a1logo-esp.pdf >. Acesso em: 26 fev. 2013.
} 
apropriação de obras de arte coloniais (pinturas cuzquenhas) em diálogo com produçóes contemporâneas. Um dos cartazes da exposição exibia as colunas de Hércules entrelaçadas pelo mote plus ultra. Entre elas, pintaram-se vários enforcados pendurados pela faixa do mote. Lado sinistro das conexôes imperiais. Conexóes sempre recordadas em antigas gravuras.

Giulio Carlo Argan demonstrou que "o princípio de leitura da obra figurativa é tipicamente seiscentista" e que o aspecto da gravura, em preto e branco, produto de uma técnica tipográfica, se assemelha mais a uma página escrita do que a uma pintura. ${ }^{39}$ Portanto, aproximamo-nos ainda mais da história das práticas de escrita ao estudarmos um elemento paratextual.

Em uma sociedade em que os meios visuais eram basilares para propagação de ideias e concepçóes, as gravuras eram muito eficazes, dada sua circulaçáo, mesmo que restrita a certos meios sociais. ${ }^{40}$ Entre as práticas letradas, na estratégia de criação do convencimento visual de um espaço muito amplo, as gravuras dos frontispícios tiveram papel fundamental, pois propagaram discursos visuais, auxiliando outros instrumentos retóricos na invenção da América e do próprio império. O repertório constituinte de tal retórica é vastíssimo, impossibilitando um enquadramento restrito a um único artista, a um único impressor, ou mesmo a um único acervo, ou seja, impedindo a realização de uma série iconográfica circunscrita. Náo obstante, este fato é representativo da eficácia e conseguinte persistência das ideias propagadas através das imagens em frontispícios e em gravuras avulsas. Propagação de atributos, alegorias, motes. Repetir o que se representava, eis uma estratégia de convencimento. Estas imagens em papéis são muito relevantes ao se analisar a cultura política do período, por isso é preciso estudar gravuras de registros teológicos e religiosos, e estampas de livros de outros gêneros.

A temática da expansão ultramarina, com um vocabulário que se consolidou ao longo do tempo, também mereceu atenção em Portugal. No entanto, entre os portugueses os feitos além-mar foram registrados mais pela pena do que pelo buril ou pelo pincel. Com exceção da Holanda que se destacou na arte de descrever visualmente suas possessóes, outras monarquias e repúblicas europeias, com interesses e domínios além-mar, também não foram tão pródigas na produção de imagens como o foi a Espanha.$^{41}$ Não desejamos com isto afirmar que inexistam referências iconográficas de tal temática em Portugal — sobressaindo esferas armilares e naus, sobretudo no período Manuelino —; destacamos, porém, que no caso espanhol houve sistematização de um discurso visual que enfatizava a dilatação planetária da monarquia, com apropriação de iconografias que persistiram durante muito tempo. Em

\footnotetext{
${ }^{39}$ ARGAN, Giulio Carlo. Imagem e persuasão. Ensaios sobre o barroco. São Paulo: Companhia das Letras, 2004. p. 18.

${ }^{40}$ Sobre a importância de meios visuais na Época Moderna, sobretudo na Espanha do período estudado, ver: MARAVALL, José Antônio. A cultura do barroco. Análise de uma estrutura histórica. São Paulo: Edusp, 2009. p. 389-405.

${ }^{41}$ ALPERS, Svetlana. A arte de descrever. A arte holandesa no século XVII. São Paulo: Edusp, 2009.
} 
contextos do dezessete, como o da Guerra dos Trinta Anos, dos debates sobre a concepção do império, da "União Ibérica" e da consolidação das possessôes ultramarinas, a imagem de um dilatamento planetário ganhava sentido político incontestável. Em tais conjunturas, colunas podiam ser muito mais do que meros ornamentos. Não à toa, são hoje ostentadas em um símbolo nacional.

Artigo recebido em 27 de fevereiro de 2013 e aceito em 3 de maio de 2013.

* O presente trabalho foi realizado com apoio do CNPq, através de uma Bolsa PDJ para pesquisa desenvolvida na Universidade Federal Fluminense. Agradeço a leitura atenta e as sugestóes de Ronaldo Vainfas, Ronald Raminelli, Sílvia Borges, Carlos Zeron, Larissa Viana e Heleno Alvares. Agradeço igualmente a Leslie Tobias Olsen, do Departamento de Imagens da John Carter Brown Library, e Daniela Pires, da Biblioteca Brasiliana Guita e José Mindlin-USP.

** Doutor em história pela Universidade Federal Fluminense. E-mail: jvictoraraujos@gmail.com. 